\title{
Article \\ (Of) Indigenous Maps in the Amazon: For a Decolonial Cartography
}

\author{
Thiara Vichiato Breda
}

check for updates

Citation: Breda, T.V. (Of) Indigenous Maps in the Amazon: For a Decolonial Cartography. ISPRS Int. J. Geo-Inf. 2022, 11, 161. https:// doi.org/10.3390/ijgi11030161

Academic Editors: Wolfgang Kainz, Fraser Taylor and Romola V. Thumbadoo

Received: 21 October 2021 Accepted: 15 January 2022 Published: 23 February 2022

Publisher's Note: MDPI stays neutral with regard to jurisdictional claims in published maps and institutional affiliations.

Copyright: (C) 2022 by the author. Licensee MDPI, Basel, Switzerland. This article is an open access article distributed under the terms and conditions of the Creative Commons Attribution (CC BY) license (https:// creativecommons.org/licenses/by/ $4.0 /)$.
Instituto de Estudos do Trópico Úmido (IETU), Universidade Federal do Sul e Sudeste do Pará (Unifesspa), Xinguara-Pará-Rua Alberto Santos Dumont, s/n, Marabá 68557-335, Brazil; thiara.breda@unifesspa.edu.br

\begin{abstract}
There are mappings of indigenous lands, mappings with indigenous participation, and mappings made by indigenous people, all of them resulting from cartographic intentions, mapping motives, and distinct meanings of spatiality. Starting from the questioning around the drives of the subject towards his search for knowledge of the space and its mapping, this article seeks to both identify the key points that these three types of mapping typically resemble and intersect, as well as to distinguish and debate them while highlighting maps made by indigenous people. This approach is based on interpretations of Mebêngôkre (Kayapó) and A'uwe (Xavante) mappings, seeking to understand them as a device of spatial organizations and representations. In doing so, we (re)position indigenous peoples as cartographer subjects who possess and produce cartographic/geographic knowledge while we question the Eurocentric legacy, expressed in an exclusivity of official/academic cartography.
\end{abstract}

Keywords: indigenous mappings; decolonial cartography; mythical spaces and indigenous orientations

\section{Introduction}

"Our thoughts expand in all directions and our words are old and many. They come from our ancestors. Yet, we do not need, like banks, image skins to prevent them from escaping our minds. We don't have to draw them, as they do with theirs. However, they will not disappear, as they are engraved within us. So, our memory is long and strong"

(Writing Drawings-Davi Kopenawa)

As a result of the European colonial civilizing process, many societies have been annihilated or silenced where geographic observations and descriptions-with their detailed information about the "new" lands-were decisive. In addition to a detailed narration of the Brasilia lands (such as the letter by Pero Vaz de Caminha), many maps were produced with the "support" of indigenous communities, which Whitehead [1] called colonial cartography:

From the moment Columbus reached the New World, geographical information was critical to further exploration and exploitation. Such knowledge was required not only to identify the location of critical resources or plunder, but also because the enlargement of the world that the event implied upset the European worldview; an unknown region needed to be incorporated into existing European cosmography [1] (p. 324).

In this process, traditional knowledge regarding the spatial representation of astronomical mappings and the marking of time by means of cyclical calendars [2] were affected, resulting in a mixture of indigenous and European conventions of spatial representations [1], with the Eurocentric norms supremacy and an appropriation of indigenous power/knowledge.

In this context, when studying South America cartographies of some cultural-linguistic groups such as Carib, Arawak and Tukano and Gê, Whitehead [1] defined three types of indigenous mappings (Table 1). 
Table 1. Types of indigenous mapping from Whitehead Source: Elaborated by the author from Whitehead [1].

\begin{tabular}{|c|c|c|c|}
\hline Categories & Types & Characteristics & Examples \\
\hline Strictly indigenous mapping & Astronomical mappings & $\begin{array}{l}\text { Closely related to cosmographic } \\
\text { mapping, usually representing } \\
\text { the shamanic visions content } \\
\text { during the flight of the soul in } \\
\text { distant regions, or representing } \\
\text { the spatial relationships } \\
\text { codified in the telluric tradition. }\end{array}$ & $\begin{array}{l}\text { A very common theme is the } \\
\text { earth and the sky connection in } \\
\text { a complex cosmographic } \\
\text { system, in which the design of } \\
\text { terrestrial features is closely } \\
\text { reflected in the patterns of stars } \\
\text { in the sky. }\end{array}$ \\
\hline \multirow{3}{*}{$\begin{array}{l}\text { Indigenous (or } \\
\text { collaborative) mapping of } \\
\text { non-indigenous interest or } \\
\text { influence }\end{array}$} & \multirow[t]{2}{*}{$\begin{array}{l}\text { “Ordered" mappings by } \\
\text { non-indigenous people }\end{array}$} & $\begin{array}{l}\text { In the colonial period, much of } \\
\text { this information was literally } \\
\text { extracted under death threat or } \\
\text { torture and was strictly for the } \\
\text { purpose of mapping } \\
\text { "conquered" lands. }\end{array}$ & $\begin{array}{l}\text { They aimed to obtain } \\
\text { geographic information such as } \\
\text { missionary work, military } \\
\text { conquest, border demarcation } \\
\text { and the search for various } \\
\text { natural resources such as } \\
\text { minerals, cocoa and rubber. }\end{array}$ \\
\hline & & $\begin{array}{l}\text { Recently, such information has } \\
\text { been offered "voluntarily" to } \\
\text { ethnographers and } \\
\text { anthropologists }\end{array}$ & $\begin{array}{l}\text { Many researchers request } \\
\text { indigenous peoples maps for } \\
\text { cosmological studies. }\end{array}$ \\
\hline & $\begin{array}{l}\text { Native spatial ideas } \\
\text { incorporated into } \\
\text { non-indigenous maps }\end{array}$ & $\begin{array}{l}\text { Many researchers request } \\
\text { indigenous peoples maps for } \\
\text { cosmological studies. }\end{array}$ & $\begin{array}{l}\text { There is an interest mainly in } \\
\text { the telluric spatial relationships } \\
\text { graphic representation. }\end{array}$ \\
\hline
\end{tabular}

For this article in particular I will focus the analysis on the first category, that of "strictly" indigenous maps of some Amazon peoples. A greater emphasis will be given to the debate on decolonial cartography because it is interesting here, and at that moment, to discuss the cartographic knowledge-power relationship beyond Cartesian methods invented by the non-indigenous. If, on the one hand, we have made progress in terms of research, development, and production of the collective construction of cartographic bases, acting directly in indigenous communities that inhabit the mapped place, on the other hand, many of these mappings are within the Cartesian cartographic reason. Thus, the intention is to join forces with these movements that question universal cartographic codes based on "typically" indigenous mapping processes.

It is important to clarify that it is not a matter of carrying out a study on the application of these maps, but of trying to understand them as a device for spatial organization and representation, positioning indigenous peoples as cartographers subject who possess and produce cartographic/geographic knowledge. Such an opening is not an ultimate end, which would only add indigenous maps (or maps of indigenous peoples) to our cartographic collection. It is a process that can destabilize the universal and pragmatic forms of mapping, stimulating a decolonization of cartography. This is how Laplantine [3] provokes us when writing about the "need" for strangeness that can be caused by cultural encounters:

In fact, trapped in a single culture, we are not only blind to that of others, but myopic when it comes to ours. The experience of otherness (and the elaboration of that experience) leads us to see what we would not have been able to imagine, given our difficulty in fixing our attention on what is usual, familiar, every day, and which we consider "evident". [ ... ] The (anthropological) knowledge of our culture inevitably passes through the knowledge of other cultures; and we must especially recognize that we are a possible culture among so many others, but not the only one [3] (pp. 12-13). 


\section{What Moves a Subject to Want to Know the Space and Map It?}

"What elements of society's culture and physical environment affect people's spatial skills and knowledge? What conditions encourage people to experience their environment and be aware of it to the point of trying to capture its essence in words and maps?"

(Spatial skills, knowledge, and place-Yi-Fu Tuan)

Tuan, in contrasting societies with different cultures-some with characteristics of subsistence agriculture restricted to a locality, others with pioneering and expeditionary characteristics, or even semi-nomadic ones-brought important contributions to cultural diversity and the development of spatial skills. Some of them are the questions in the heading that opens this section [4] (p. 101). I add others, more specific to our dialogue for this text: Cartographic knowledge is only valid when the map is written on a material means of communication? What moves a subject to want to know the space and map it? Are the motives and interests of indigenous mapping the same? What are the indigenous cartographic forms and intentions?

I share these questions here not with the intention of answering them in a single article. They are here as gears that have the purpose of stimulating us to possible reflections on "mapping reasons", based on the need (or the absence!) of permanent records. Therefore, they involve a specific conception of knowledge and relationship with the world.

Many indigenous cultures are marked by oral tradition, in which, until colonization, there was no need for permanent records, either of linear writing or of spellings with spatial information, in durable materials characteristic of Western society, as we can see in the words from shaman Davi Kopenawa:

"I don't have old books like them, in which the stories of my ancestors are drawn. The xapiri's words are engraved in my thoughts, deep inside me. [ ... ] I didn't learn to think the forest things by fixing my eyes on paper skins. I saw them for real, drinking my ancients' breath of life with the yäkoan powder they gave me [ ... ]. Omama did not give us any book showing the drawings of Teosi's words, like the white people. He put his words inside of us." [5] (pp. 65, 75, 77).

It is important to emphasize with this that the record forms and functions of the transmissions of indigenous spatial information are distinct from those of non-indigenous societies. If we are going to look for indigenous maps, we need to expand the map concept beyond maps that are graphed on paper. Tuan [4] when talking about short-lived maps, questions for example what the occasions are when a "physical", "drawn" map would be necessary, and when a mental map, with only the verbal description of the path and nature of the terrain would be enough.

Woodward and Lewis [6] present a production and spatial records cartesian classification of non-Western cultures, organized into three categories that can help us here in our reflection (Table 2).

Table 2. Categories of Representations of Non-western spatial thought and expression. Source: Woodward e Lewis [6] (p. 3).

\begin{tabular}{|c|c|c|}
\hline $\begin{array}{c}\text { Internal } \\
\text { (Inner Experience) }\end{array}$ & \multicolumn{2}{|c|}{$\begin{array}{c}\text { External } \\
\text { (Processes and Objects that Realize or Externalize the Internal Experience) }\end{array}$} \\
\hline $\begin{array}{l}\text { Cognitive Cartography } \\
\text { (Thought, Images) }\end{array}$ & $\begin{array}{l}\text { Performance Cartography } \\
\text { (Performance, Processes) }\end{array}$ & $\begin{array}{l}\text { Material Cartography } \\
\text { (Record, Objects) }\end{array}$ \\
\hline Organized images such as spatial constructs & $\begin{array}{c}\text { Nonmaterial and ephemeral } \\
\text { Gesture } \\
\text { Ritual } \\
\text { Song } \\
\text { Poem } \\
\text { Dance } \\
\text { Speech } \\
\text { Material and ephemeral } \\
\text { Model } \\
\text { Sketch }\end{array}$ & $\begin{array}{c}\text { In situ } \\
\text { Rock art } \\
\text { Displayed maps } \\
\text { Mobile comparable objects } \\
\text { Paintings } \\
\text { Drawings } \\
\text { Sketches } \\
\text { Models } \\
\text { Textiles } \\
\text { Ceramics } \\
\text { Recording of "performance maps" }\end{array}$ \\
\hline
\end{tabular}


From this perspective, what we could often judge to be just a cultural artifact are also cartographies in processes [7] of mapping movements [8] that register a spatial organization, a way of being in the world that still does not fit into the molds and cartographic models that we (the non-indigenous) created. Many of them use oral and performance communication to convey meaningful information. "The actions, lasting hours or days, carry greater meaning than any object they produce." [7] (p. 3). Perhaps the transfer of spatial information to permanent communication materials, creating forms and norms for cartographic visualizations, is particularly a Western interest where "seeing is knowing and picturing is power" [1] (p. 321).

It is as stated by Whitehead "The issue here seems to be less a question of cartographic ability than an issue of cartographic forms and purposes" [1] (p. 320). In the same sense, Pinheiro [9] (p. 154) reminds us that "[ ... ] the cartographic map is not the surface on which it is placed. The physical environment works only as a support because the true map is an abstraction". Tuan already provided important reflections for these arguments, stating that "[ ... ] spatial skill is essential for subsistence, while spatial knowledge, at the level of symbolic articulation in words and images, is not" [4] (p. 97). A person may not know how to give his location or draw a "precise" map (which would be the systematic spatial knowledge linked to cartographic techniques in Western culture), but they may have the ability to find themselves, to have a direction intuition in their own action with the environment. Thus, the absence of conscious and/or conceptualized geographic knowledge does not directly refer to the lack of spatial skills and (spontaneous) geographical competences [10].

Tuan endorses this dialogue by stating that " $[\ldots]$ conscious knowledge can even hinder the performance of a skill" [4] (p. 90). Knowing the cardinal and collateral points or knowingly handling topographic maps is not enough of a guarantee for a trip in an unknown forest, for example. This may require other spatial and mnemonic skills.

Looking at this direction, we can see that many indigenous mappings integrate spatial skills with celestial, social, philosophical, and cosmological elements, and are encoded in their origin's history, in the architecture of houses, in the organization of villages and in material artifacts, particularly in basketry.

This integration is evident in the east-west layout of villages, the encoding and placing of village structures in accordance with the daily movement of celestial entities, the cardinal directionality of ceremonial processions, the movement of men to different houses in the village during their life cycles, the location of particular kinship units within the village, and the coordinated positioning of villages that exchange marriage partners. [1] (p. 305).

\section{Cardinal Points and the A'Uwe People Path of the Sun}

For the $A^{\prime}$ uwe, the distribution of houses and the divisions of the Poreza'onno (tadpole) and Öwawê (big water) clans, the hö (boys' house) location and the delimitation of some paths symbolically express alignments of the path of the sun (east-west cardinal points) and are connected with the universe creation history (Figure 1). During my visit to the Êtêñiritipa village, I asked the chief about his origins. Jurandir Siridiwê Xavante, pointing towards the east, told me: "we came from there. There, where Siruro comes out, that very big star from where the sun comes (Figure 1)". 
Höiwa podo, um desenho do céu

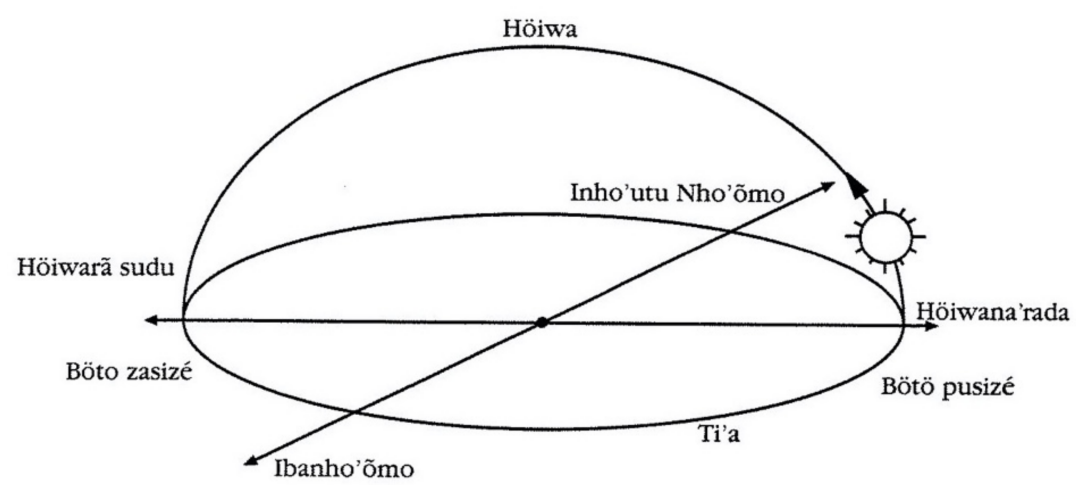

Figure 1. Illustration of the Xavante world concept and forms of spatial orientations. Source: Shaker [11] (p. 79).

Shaker [11], when recording in writing the A'uwê (höizwana'rada) origin and the history of the darkness time creation (Rómraréhã rówasu'u) of the Xavante world, claim that:

Höiwana'rada is the root from which the A'uwê originate. It is the root of everything. The stories will tell: it is the heaven root; from there the sky arose, and from there the movement of its closing and spreading will take place; it is the moon, sun and stars root. The A'uwê also originated there; it was from there that they started walking. It is the east, the birthplace of everything that was created. Etymologically, it is the root, the origin (na'rada) of the sky (höiwa). It is the root of space, of places (ro). It is a place, pointed out by the gestures of ancients, "the people always pointed there (the East)". But it is more than a physical place; it is the cosmological root from which what will be created is born, the sky, the moon, the sun, the stars, the $A^{\prime}$ uwe people. The other end of the sky, the west, the sunset, the tip of the sky down, is höiwara a sudu, where, with its spreading, the sky will close. Höiwana'rada is origin as a physical and temporal space; it is origin as a cosmological root. And it is the door through which you enter the postmortem path. (p. 54).

In this sense, I would like to detail some notes taken during my stay in Êtêñiritipa. They were drafted right there, and now organized for the writing of that text [10,12].

Field Notes-October 2017

In one of our conversation circles about A'uwe geography and Waradzu geography, Eurico Xavante, the school coordinator, took out of the gray metal locker a compass that he had received with other school supplies, and asked me how to use it. I made a sketch on the blackboard indicating the cardinal points marked on the compass and quickly Valmir Xavante (one of the teachers) made a drawing on the paper indicating the terms böto puisizé (where the sun rises) and bötö zasizé (where the sun goes down) (Figure 2). When I asked about the north and south points, Valmir, Eurico and Vinicius looked at each other, talked to each other in gê and told me that they didn't have a term (for it). They called one of the oldest elderly and there they started a long conversation in Gê. At times, they translated the questions raised. Some suggested terms, others disagreed. One of them mentioned the terms romhöimo and ropi'reba. But there was quickly a rejection of the others. At the time, I did not understand the reason for the disagreement. I just wrote down the terms in my diary. At the end they informed me that they reached to the decision that they did not have a word in Gê to express these two points (north and south). They were not interested there at that time to "translate" them. They indicated the points in the sketch, ended the subject, handed me the diagram saying, "here is the höiwa podo, the drawing of the sky". One of them quickly complemented "botö nebdzé rob u". There was consensus on this second term. I asked if it was the translation of cardinal points. I was told not, but actually, that it meant "the path that the sun takes to a place of reference". On 
another day, when one of the women showed me the Xavante = Portuguese dictionary of the Salesian mission, I found the following definition for the terms: Romköimo, ro (place) and köimo (top); and ropi'reba, ro (place) and pi'reba (bottom).

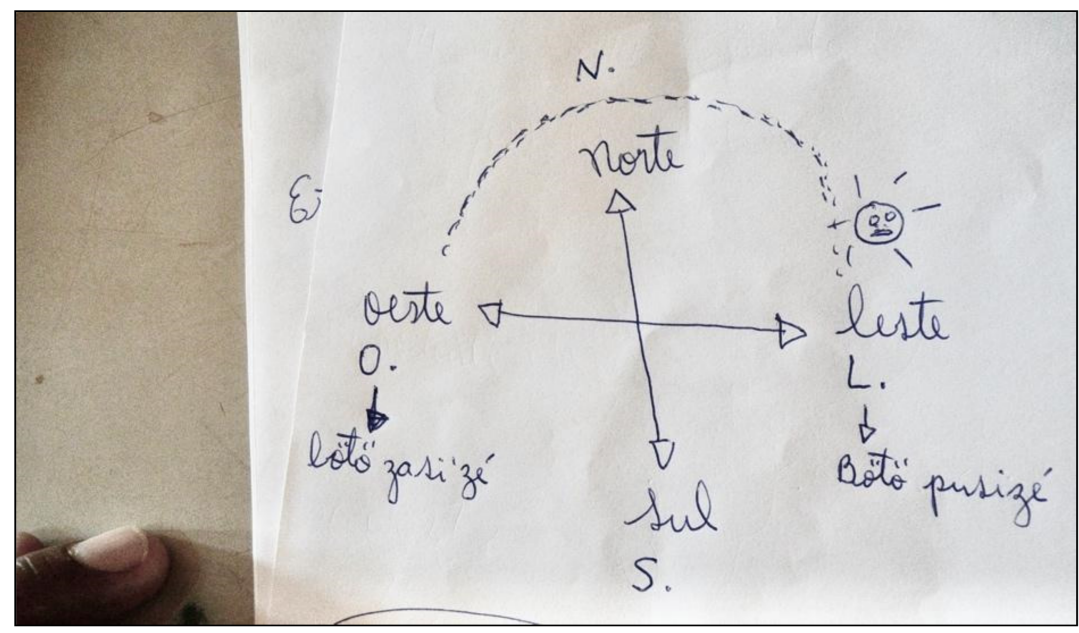

Figure 2. The path of the sun (east-west axis)—Drawing by Valmir Xavante. Source: Field record, 2017.

From the report we can bring up two discussions: the first is about the use of cartographic references nomenclatures related to vernacular geographic knowledge with the cosmology of that culture and that can reveal skills, senses and spatial representations that are beyond conceptual apprehension. They can guide themselves and move easily without the concept or nomenclatures of the cardinal points appearing, or even without directions being graphed/mapped.

The Xavante of Êtêñiritipa, for the most part, no longer travels great distances. Their trips are often for fishing, hunting, collecting eggs and fruits. This is limited by the indigenous lands marking, unlike before colonization, when they presented characteristics of semi nomadism. Today, they have a detailed knowledge of the Indigenous Lands (IL) and landmarks in the sky and in the relief, constituting a "true mental map" [10]. As Tuan points out: "[ ... ] it is possible to determine the path through position calculations without using astronomical observations and through considerable experience in trying to draw global spatial relations of locality" [4] (p. 101).

The second point is about the "forced" translation, the result of the non-indidigenous needs to find a translation for the Eurocentric reference points and which, apparently, for the Xavante, are of no use, since they rely on natural aspects to guide themselves. Only east and west are visible points from the "path that the sun takes" in the sky. It is added that these two points are differentiated not only as east or west, but also as an analogy of the sunrise associated with the light and the sky, and the west with the darkness and the earth.

The problem is further intensified by the fact that the translation made by the Salesian missionaries is based on an image that fixes the north "above" and the south "below" from the east "to the right", and the west "to the left", as we are usually used to drawing in the wind rose and orienting our bodies (turning our back to the south!).

If we observe the trajectory of cartography, for many years the east (orient) direction was the main reference to the attitude of orienting oneself. The very origin of the verb "to orient" comes from the Latin "to go to the east". It was only with the compass invention, through the discovery that the magnetized needle aligns with the Earth's magnetic axis, that the direction of north-south orientation was defined. With this, throughout the European Renaissance, it was agreed that the compass would point to the north, painting the $\mathrm{N}$ red, and/or creating an arrow with a north direction (Figure 3). Thus, determining that the compass "points" to the north is a European cartographic convention, since the needle does not point in a single direction (with the insistence on the north), but rather its tips (or magnetic poles) align with the terrestrial magnetic poles: the north pole of the needle 
points to the magnetic south pole of the Earth (geographic north) at the same time that the south pole of the compass needle points to the magnetic north pole of the Earth (geographic south pole).

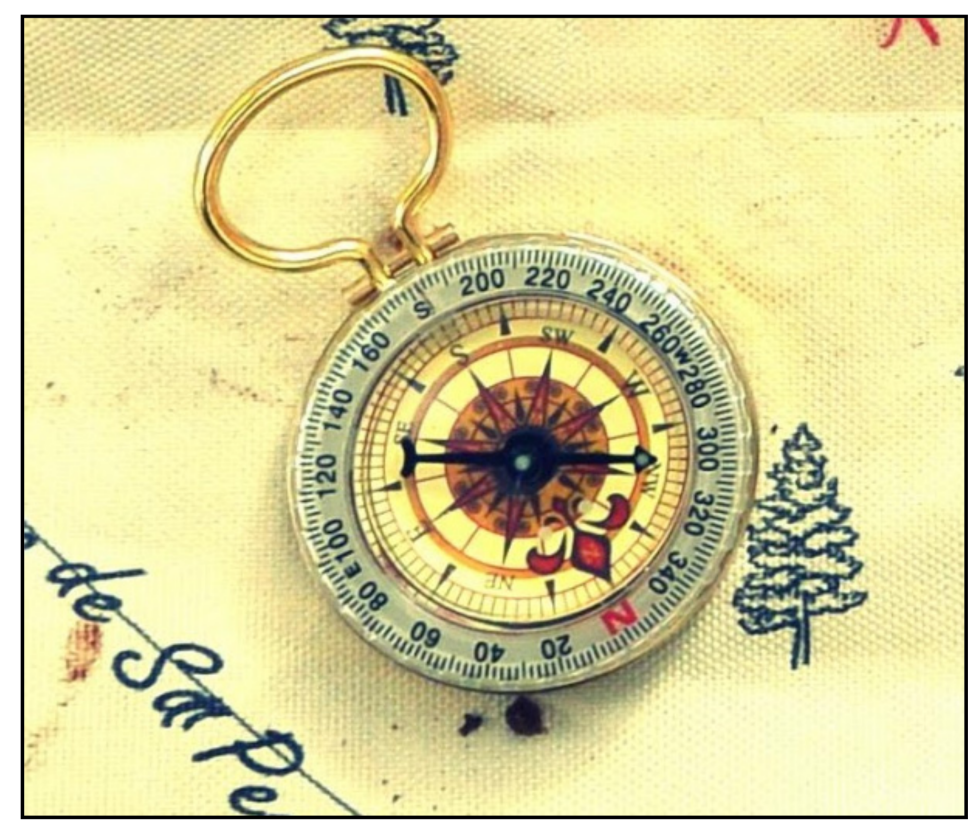

Figure 3. Compass with an indication of the north direction. Source: the author.

\section{Oriented Mythical Spaces and the Mebêngôkre People Universe}

The east-west (sunrise-sunset) axis orientation mentioned above also occurs in Kayapó society; however, with some differences. According to Campos [13,14], instead of standing up to look for points Káikwa nhôt (west) and Káikwa krax (east) as is normally done in Western culture, they lie on the floor with their feet facing east and belly button facing upwards, as shown in Figure 4:

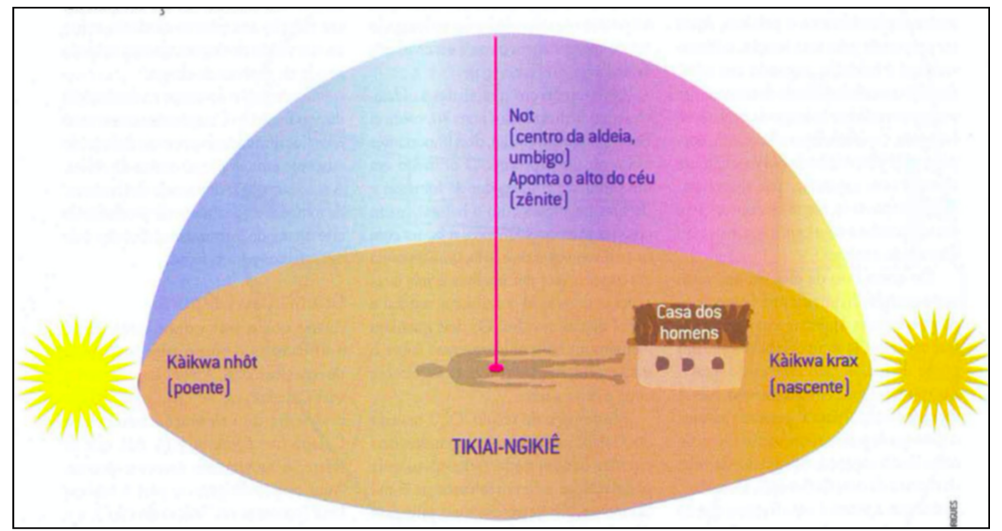

Figure 4. Kayapó orientation. Source: Campos, [13] (p. 66).

This would be a cosmological scheme in which man is not only positioned in the center to orient himself, but also, he is the "center of the world" and the spatial plane is defined by the sun-body reference points. Tuan called these characteristics a mythical space, stating that "[ ... ] it satisfies the intellectual and psychological needs; saves appearances and explains events" [13] [p. 118]. Therefore, some characteristics of these representations are common among ethnic groups, namely:

It organizes the forces of nature and society by associating them with significant locations or places within the spatial system. It tries to make the universe understandable by classifying 
its elements and suggesting that there are mutual influences between them. [ ... ] Assign personalities to the space, consequently transforming the space into place [13] (p. 117)

As Whitehead [1] (p. 316) points out, in the indigenous conceptions:

"[ ... ] ideas about the interconnection between persons and the cosmos may be enacted directly in ritual, through the design of costume and dance movements, or in songs through ritual that the cosmic order is maintained. Both the costumes of dancers and the shamanically prescribed movements refer to the cosmos ".

The mekutom ceremonial headdress and the helmet used by the Kayapó, for example, contain highly symbolic codes linked to their creation history and reveal much of these conceptions that include spatial references (Figure 5).

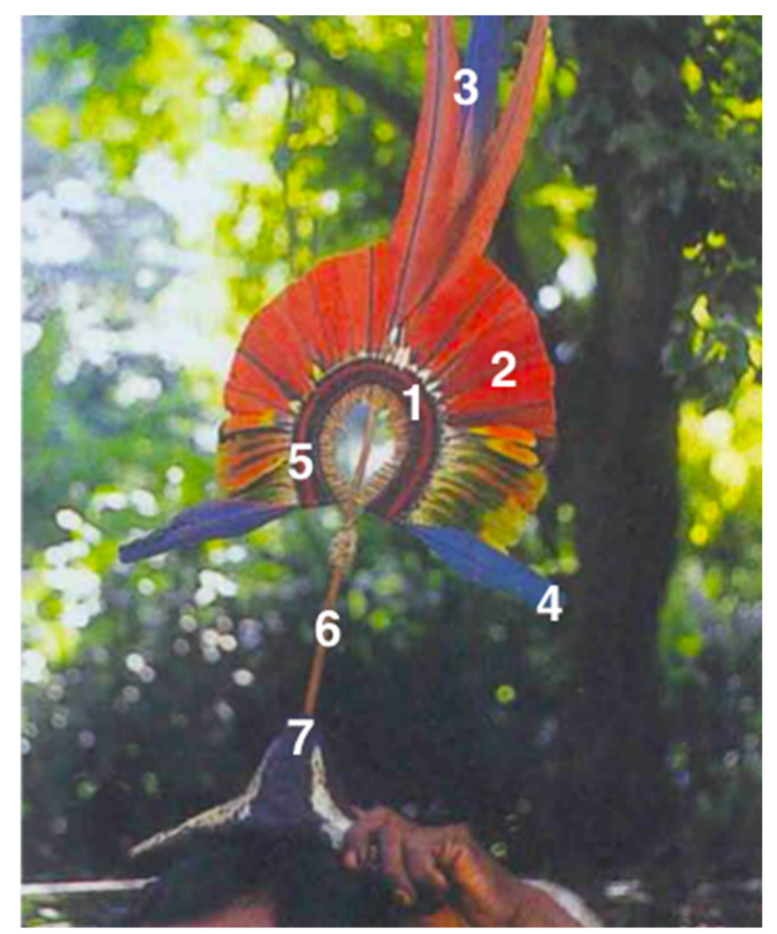

Figure 5. Mekutom ceremonial headdress and helmet. (1) The arch that supports the feathers represents the layers of the upper world (pykra). (2) The feathers red macaw, blue macaw and parrot feathers represent the face of the sun. (3) The three most elongated central feathers are the nose and the eyes of the sun. (4) The more elongated feathers on the sides portray the ears of the sun. (5) The path of the sun in this world is represented by the red stripe, uniting the east and the west. (6) The rod symbolizes the cord used by ancestors to descend into this world. (7) The helmet framed with beeswax mixed with remnants of dried vegetables is shaped like a freshwater turtle or tracajá. The highest part of the helmet symbolizes the center of the world and the location of the first village.

Thus, the mekutom represents regions of these disks, expressing not only the location, but also the Kayapó identity and some relations with the deities, provoking analogies that delineate the physical space and the spiritual space, encoded in the headdress. They are, therefore, "[ ... ] physical maps and metaphysical terrains, since it is vital to establish the correct place of human with regard to multiple domains, not just the geographical" [1] (p. 312).

This importance given to the east-west axis that we mentioned earlier, as well as the mapping of the universe "real" and "imaginary", incorporating elements of celestial deities in the mekutom, have already been realized by the European cartography of the beginning of the Renaissance [1], as well as for medieval Christian cartography and its representations of religious mysteries, heaven and hell [15]. 


\section{Final Notes}

"Brazil's mother is indigenous, although the country is more proud of its European father who treats him as a bastard son. His root comes from here, from the ancestral people who wear a story, who write their culture, their prayers and their struggles on the skin."

(Brazil's mother is indigenous-Mirian Krexu)

As we have seen here, some maps produced by indigenous people are not necessarily mappings centered on their spatial references, cosmological beliefs and living conditions. In some projects, the reasons for mapping are stimulated by the researcher and the concern is linked more to environmental conservation in defense of the environment than to issues that are properly indigenous. We often call on indigenous communities as mapping agents to make a commitment to preserve the environment- that is, natural resources [16]. However, the concern for environmental conservation today is markedly around the the non-indigenous lifestyle. It's how Aguiar provokes us: “[ . . ] if there was no concern with environmental conservation, would there be a focus on the discussion on the creation and demarcation of indigenous areas" [16] (p. 239).

It is essential to recognize the importance of this type of mapping when including, for example, indigenous communities as subjects who map their own territories. But it is also necessary to recognize that, if on the one hand this mapping has been useful and desired and gives visibility to some indigenous spellings (mainly in the choices of the maps subtitles), on the other hand it has created a confusion that these maps are indigenous mappings (or mapping of indigenous peoples).

Although many cultural/social cartography projects involve participatory maps in sensitive attempts to incorporate indigenous elements/themes, as in the themes determination (mapping reasons), for example, these maps are not always configured as indigenous maps (or maps of indigenous peoples). When ordered/induced by non-indigenous people, a certain way of conceiving and representing space is implicit, and they are often incapable: “[ ... ] thought as applied to cartography, focusing especially on its inability to account for mapping in non-textual, non-Cartesian cultures where action and process are often crucial, and " $[\ldots]$ even more paradoxical is the aim to include the excluded-to empower the disempowered—and to make no claims for textual superiority," [7] (pp. 1, 6).

Thus, caution is required when referring to "indigenous map (or maps of indigenous peoples)", since this term has been used in several situations, including participatory mapping in which the interest and the cartographic reason are of the researcher, ethnologist, or even of curious people. Given the ideas exposed here in our dialogue, my understanding is that we should use this term for mappings that explicitly contain indigenous representational knowledge, motives and forms, even if these are "abstract", "indecipherable" or "impossible" for us non-indigenous geographers. My intention here is not to create elements or criteria that identify what is indigenous cartography (or cartography of indigenous people), but to verify signs of an originality in their mappings.

In this sense, Whitehead points out that many cartographic representations have been produced today by indigenous people to help exogenous learning:

"[ [... ] and to make up for the interrogators' lack of linguistic, as much as geographic, understanding. As a result, we cannot simply assume that such exercises were part of a native tradition. They should be seen as providing evidence of the flexibility of indigenous cartographic practice as well as highlighting the differing cartographic needs of "locals" and "strangers" [1], (p. 319).

Much of what we call "indigenous maps" are formed as a palimpsest, in which colonialist cartographic motives for dissecting natural wealth are erased to engrave new reasons over those that existed before, even if still within Western cartographic reason, with Cartesian traditions and codifications. Change the style and color of the spelling, but the paper is the same! As a result, the erasure is imperfect and evident, leaving traces of a western dualism of mind and world, and of an objectification of the Earth. The point of view of a 
mapping from the high, distant and detached from the Earth, prevails [7]). Man and nature remain unified, and the Earth is mapped as a provider of natural resources. We cannot forget that understanding nature as outside of man was and still is a maneuver that allows us to explore the "empty" space [17].

In some indigenous cosmologies, nature is understood in its global sense, in which everything is nature, including each one of us [18]. This means that, unlike (my) naturalistic Eurocentric Christian cosmology, which objectifies (and explores) the Earth, many indigenous ethnic groups "personify" it through the presence of spirits in animals, plants, objects, or places. It is necessary, as Rundstrom warns us, to be careful not to be nihilists and to suffocate, distort or isolate indigenous mappings (or mappings of the indigenous peoples) from our projects/research of cross-cultural cartographic/geographical situations that also include worldviews and our place in it. Becoming aware of the colonial/colonizing cartographic heritage requires, as Rundstrom says, "a balance between keeping some differences and overcoming others if we are to achieve a society that is tolerant of difference and yet fair to all of us." [7] (p. 5), and that has been one of the decolonial turn challenges.

When analyzing decolonial thinking in geography, Cruz [19] points out that even with the end of the economic and political colonial period (historicized between the 16th and 19th centuries), coloniality is still an irreducible residue in our social formation and in our way of produce knowledge, "[ ... ] manifesting itself in the most varied ways in our political and academic institutions, in the domination/oppression relations, in our authoritarian sociability practices, in our memory, language, social imaginary, in our subjectivities [ . . . ]" [19] (p. 15). By eliminating ways of living, relating and representing, or self-representing ourselves, we commit an epistemicide [20] that makes it impossible or expropriates (from) the other (from) their subjectivities and, in the cartography case, their cosmological symbolic systems that the other (person) has of the world and of themselves" [ . . ] as well as of their concrete forms of representations and record of their memories and experiences " [19] (p. 17).

The criticism of the colonial form of cartographic representations implies an epistemological, political, and ethical commitment to participatory mapping of/with/for indigenous people. That is why I defend a decolonial cartography and not a counter-cartography. This movement is not against it, but it takes a different path, which follows in the same direction as social and cultural cartographies, which have generated precious debates by "tensioning" the western official/academic cartography. In other words, decolonial cartography is a movement that, by "[ ... ] placing our colonial past as a starting point to press the specificity of our societies" [19] (p. 23) questions the cartographic exclusivity linked to the modern science and its society project, marked by a Eurocentric worldview that conceives space as a resource [21], as a surface to be dominated [17], and as a marketing product/property [19].

An indigenous decolonial mapping proposes to be a fairer and more inclusive approach, which allows us to know and recognize a way of living, of being, of thinking, of representing differently from the predominant model of westernized society. It makes room for maps that are not just prescriptive, centered on the usefulness or need of the capitalist system of territory control and resources exploitation written on paper skins [22].

Finally, I would like to make it crystal clear that this is a reflection of a white, Brazilian researcher, of European descent, and who has been developing projects in this area. For this reason, I have shared here some cartographic anxieties and cosmological care that seem important to me when we talk about indigenous cartographies. Having decoloniality as an epistemological stance and being motivated by cross-cultural interests have led me to radically review my uncomfortable place as a researcher and as a person in the world. Just as Theo Evan [23] was concerned with delivering a compass to the Tuschaua leader, we need to become aware of our cartographic acts/projects with/from/for indigenous people.

Funding: The publication of this article was funded by Geomatics and Cartographic Research Center Institution.

Data Availability Statement: Not applicable. 


\begin{abstract}
Acknowledgments: It was a privilege to have the opportunity to meet the Xavante. For that, I am very grateful to Tadeu de Oliveira for the invitation and to the Aldeia Êtêñiritipa, in the figure of the chief Jurandir Siridiwê Xavante, for the welcome, and for sharing their songs, their dances, their knowledge, their handicrafts and paintings. More than just knowing a culture, it was a possibility to walk paths that also led to meeting myself. I also thank the work partners Anniele Freitas, for the constant reflective/intensive dialogues, and Elionete Garzoni, for the careful reading and comments on this text. This is a translation of Mapas (de) indígenas na Amazônia: por uma cartografia decolonial originally published in Revista Ciência Geográfica Ensino-Pesquisa-Métodoin 2021. v.XXV, p. 282-299 (https: / / www.agbbauru.org.br/revista_xxv_1.html accessed on 10 October 2021). Permission was granted by Editora Saraiva. I would also like to thank the technical support of the SPRS International Journal of Geo-Information and the Guests Editors Dr. Fraser Taylor and Dr. Romola V. Thumbadoo for their support and encouragement of this publication.
\end{abstract}

Conflicts of Interest: The authors declare no conflict of interest.

\title{
References
}

1. Whitehead, N. Indigenous Cartography in Lowland South America and the Caribbean. In The History of Cartography, Volume 2, Book 3: Cartography in the Traditional African, American, Australian and Pacific Societies; Woodward, D., Lewis, G.M., Eds.; University of Chicago Press: Chicago, IL, USA, 1998; pp. 301-326.

2. Campos, M.D. Fazer o tempo' e 'o fazer do tempo': Ritmos em concorrência entre o ser humano e a natureza. Ciência Ambiente 1994, 8, 7-33.

3. Laplantine, F. Aprender Antropologia; Brasiliense: São Paulo, Brazil, 2003.

4. Tuan, Y.-F. Espaço e Lugar: A Perspectiva da Experiência; Eduel: Londrina, Brazil, 2013.

5. Kopenawa, D.; Albert, B. A Queda do Céu: Palavras de um Xamã Yanomami; Companhia das Letras: São Paulo, Brazil, 2015.

6. Woodward, D.; Lewis, G.M. Introduction. In The History of Cartography. Volume 2 Book 3: Cartography in the Traditional African, American, Australian, and Pacific Societies; University of Chicago Press: Chicago, IL, USA, 1998.

7. Rundstrom, R. Mapping postmodernism: Indigenous people and the changing direction of North American cartography. Cartographica 1991, 2, 1-12. [CrossRef]

8. Cosgrove, D. Mappings; Reaktion Books: London, UK, 1999.

9. Pinheiro, J.Q. Mapas cognitivos do mundo: Representações mentais distorcidas? In A Aventura Cartográfica: Perspectivas, Pesquisas e Reflexões Sobre a Cartografia Human; Seemann, J., Ed.; Expressão Gráfica: Fortaleza, Brazil, 2005; pp. 151-169.

10. Breda, T.V. Políticas curriculares em contextos amazônicos: Os desafios para uma educação indígena com/na/pela diferença. Revista Ciência Geográfica Ensino-Pesquisa-Método. Dossiê Ensino Geogr. 2020, XXIV, 353-674.

11. Shaker, A.; Serezabdi, P.; Serenhimirãmi, P.; Hipru Supretaprã, P.; Prépe, A. Romhõsi'wai Hawi Rowa'õno re Ihöimana Mono: A Criação do Mundo Segundo os Velhos Narradores Xavante (Fundamentos Primeiros para uma Antropologia Espiritual). São Paulo, Brazil. 2012. Available online: https://www.cpei.ifch.unicamp.br/pf-cpei/\%20/EidArthurShakerFauzi.pdf (accessed on 10 October 2021).

12. Breda, T.V. Entre escritos, imagens, memórias e experiências espaciais. In Geografias Literárias: Escritos, Diálogos e Narrativas; Portugal, J.F., Ed.; EDUFBA: Salvador, Brasil, 2020.

13. Campos, M.D.A. Cosmologia dos Caiapós. Rev. Sci. Am. Bras. Espec. Astron. 2006, 14, 62-71.

14. Campos, M.D. Por que SULear? Astronomias do Sul e culturas locais. In Perspectivas Etnográficas e Históricas sobre as Astronomias; Faulhaber, P., Borges, L.C., Eds.; Museu de Astronomia e Ciências Afins: Rio de Janeiro, Brazil, 2016; pp. $215-240$.

15. Seemann, J. Histórias da Cartografia, Imersão em Mapas e Carto-Falas: Métodos para estudar culturas cartográficas. In Grafias do Espaço: Imagens da Educação Geográfica Contemporânea; Cazetta, V., Oliveira Junior, W.M., Eds.; Alínea: Campinas, Brazil, 2013 ; pp. 87-106.

16. Aguiar, J.V.d.S. Narrativas Sobre Povos Indígenas na Amazônia; Edua: Manaus, Brazil, 2012.

17. Massey, D. Pelo Espaço. Uma Nova Política das Espacialidades; Bertrand Brasil: Rio de Janeiro, Brazil, 2015.

18. Krenak, A. Ideias Para Adiar o Fim do Mundo; Companhia das Letrinhas: São Paulo, Brazil, 2019.

19. Cruz, V.d.C. Geografia e pensamento descolonial: Notas sobre um diálogo necessário para a renovação do pensamento crítico. In Geografia e Giro Descolonial: Experieências, Ideias e Horizontes de Renovação do Pensamento Crítico; Cruz, V., Do, C.O., Araújo, D.d., Eds.; Letra Capital: Rio de Janeiro, Brazil, 2017; pp. 15-36.

20. Souza Santos, B.D. A Crítica da Razão Indolente: Contra o Desperdício da Experiência; Cortez: São João, Brazil, $2002 ;$ Volume 1.

21. Tuan, Y. Images and Mental Maps. Ann. Assoc. Am. Geogr. 1975, 65, 205-212. [CrossRef]

22. Breda, T.V. Razões cartográficas e motivos de mapeamentos: Notas sobre representações espaciais indígenas. Raega-O Espaço Geográfico em Análise 2021, 52, 151-171.

23. Sierpente, El Abrazo de la. Direção Directiono de Ciro Guerra. Esfera Cultural. 2016. Available online: https://iffr.com/nl/iffr/20 16/films / el-abrazo-de-la-serpiente (accessed on 10 October 2021). 